P-ISSN 2580 - 7781

E-ISSN 2615 - 3238

\title{
ANALISIS PENGARUH INDEKS PEMBANGUNAN MANUSIA DAN TENGA KERJA TERHADAP KEMISKINAN DI PROVINSI SUMATERA UTARA
}

\section{ANALYSIS OF POVERTY INFLUENCE ON HUMAN DEVELOPMENT INDEX AND LABOR IN NORTH SUMATERA PROVINCE}

\author{
Dessy Chayani Elisabeth Sitanggang \\ Universitas Sumatera Utara \\ Email : dessychayani@gmail.com
}

\begin{abstract}
ABSTRAK
Kemiskinan terus menjadi masalah utama dunia, Khususnya di Provinsi Sumatera Utara. Penelitian memiliki tujuan menguji dan menganalisis Pengaruh Indeks Pembangunan Manusia dan Tenaga Kerja Terhadap Kemiskinan di Provinsi Sumatera Utara. Jenis data menggunakan data sekunder yang diperoleh dari BPS Indonesia dan juga jurnal sebagai pendukung penelitian. Analisis yang digunakan dalam penelitian ini adalah metode kuantitatif dan menggunakan eviews10. Dalam model ini variabel independen yang digunakan adalah Indeks Pembangunan Manusia dan Tenaga kerja. Sedangkan variabel dependen adalah Kemiskinan. Hasil Regresi menunjukkan Koefisien Korelasi (R) diperoleh korelasi berganda sebesar $\mathrm{R}=0.53$ atau sebesar $53 \%$ maka dapat disimpulkan bahwa terdapat hubungan keeratan korelasi yang kuat antara variabel IPM dan Tenaga Kerja terhadap Kemiskinan di Provinsi Sumatera Utara. Koefisien Determinasi (R2) dari hasil perhitungan koefisien determinasi (R2) sebesar 0,06 atau 6\% artinya 6\% kemiskinan di Provinsi Sumatera Utara dipengaruhi oleh IPM dan Tenaga Kerja. Sedangkan 94\% dipengaruhi oleh variabel lain yang tidak diteliti.
\end{abstract}

Kata Kunci : Kemiskinan, Indeks Pembangunan Manusia, Tenaga Kerja

\begin{abstract}
Poverty continues to be a major global problem, particularly in North Sumatra Province. The research aims to test and analyze the Effect of the Human Development and Labor Index on Poverty in North Sumatra Province. This type of data uses secondary data obtained from BPS Indonesia and also journals as research support. The analysis used in this study is a quantitative method and uses eviews10. In this model the independent variable used is the Human Development Index and Labor. While the dependent variable is poverty. Regression results show the Correlation Coefficient $(R)$ obtained by multiple correlations of $R=0.53$ or by $53 \%$, it can be concluded that there is a strong correlation between the HDI variables and the Workforce on Poverty in North Sumatra Province. The coefficient of determination (R2) from the calculation of the coefficient of determination (R2) of 0.06 or $6 \%$ means that $6 \%$ of poverty in North Sumatra Province is influenced by HDI and labor. While $94 \%$ is influenced by other variables not examined.
\end{abstract}

Keywords: Poverty, Human Development Index, Labor

\section{PENDAHULUAN}

Pada Hakikatnya pembangunan adalah proses perubahan yang berjalan secara terus menerus untuk mencapai suatu kondisi kehidupan yang lebih baik secara spiritual maupun material. Pembangunan haruslah dipandang sebagai suatu proses multidimensional yang mencakup berbagai perubahan struktur sosial, 
P-ISSN $2580-7781$

E-ISSN 2615 - 3238

sikap-sikap masyarakat, serta istitusi-institusi nasional, disamping tetap mengejar akselerasi pertumbuhan ekonomi, penanganan ketimpangan pendapatan dan pengentasan kemiskinan ( Todaro dan Smith, 2006) sebagai suatu proses, pembangunan tentu saja dilakukan dengan melihat kebutuhan-kebutuhan yang ada sekaligus merespon perubahan yang terjadi dalam masyarakat dan tuntutantuntutan pergeseran waktu akibat berkembangnya peradaban, sistem sosial kemasyarakatan dan teknologi yang lebih maju.

Kemiskinan terus menjadi masalah utama dunia, khususnya Indonesia yang menjadi negara berkembang. Kemiskinan yang terjadi pada suatu negara dilihat menjadi permasalahan yang serius, karena pada masa sekarang kemiskinan membuat masyarakat Indonesia tidak bisa berkembang. Menurut M.Nasir (2008) permasalahan kemiskinan merupakan permasalahan kompleks dan multidimensi. Kemiskinan di Indonesia disebabkan oleh berbagai faktor, yaitu tingkat upah kurang, tingkat pengangguran yang tinggi dan IPM yang masih kurang. Dapat dikatakan miskin apabila belum bisa mencukupi kebutuhannya atau belum berpenghasilan.

Salah satu tolak ukur yang digunakan dalam melihat kualitas hidup manusia adalah Indeks Pembangunan Manusia (IPM) yang diukur melalui kualitas tingkat pendidikan, kesehatan dan ekonomi (daya beli). Melalui peningkatan ketiga indikator tersebut diharapkan akan terjadi peningkatan kualitas manusia. Keberhasilan pembangunan manusia tidak dapat dilepaskan dari kinerja pemerintah yang berperan dalam menciptakan regulasi bagi tercapainya tertib sosial.

Pemerintah sebagai pelaksana pembangunan tentunya membutuhkan modal manusia yang berkualitas sebagai modal dasar pembangunan. Untuk menghasilkan manusia yang berkualitas diperlukan upaya-upaya untuk meningkatkan kualitas SDMnya. Menurut (Ginting, 2008) menyatakan pembangunan manusia di Indonesia adalah identik dengan pengurangan kemiskinan. Investasi dibidang pendidikan dan kesehatan akan lebih berarti bagi penduduk miskin dibandingkan penduduk tidak miskin, karena asset utama penduduk miskin adalah tenaga kasar mereka. 
P-ISSN $2580-7781$

E-ISSN 2615 - 3238

IPM membahas penduduk pada suatu wilayah memiliki kesempatan memperoleh hasil pembangunan dari haknya untuk mendapatkan pendidikan, pendapatan dan kesehatan. Selain itu IPM juga digunakan mengklasifikasikan apakah sebuah negara termasuk dalam kategori negara maju, negara berkembang atau negara terbelakang.

Tenaga kerja merupakan penduduk yang berada dalam usia kerja. Menurut UU No. 13 tahun 2003 Bab I pasal 1 ayat 2 disebutkan bahwa tenaga kerja adalah setiap orang yang mampu melakukan pekerjaan guna menghasilkan barang dan atau jasa baik untuk memenuhi kebutuhan sendiri maupun untuk masyarakat. Secara garis besar penduduk suatu negara dibedakan menjadi dua kelompok, yaitu tenaga kerja dan bukan tenaga kerja.

Kemiskinan dapat ditinjau dari berbagai sisi, salah satunya dari ketenagakerjaan. Pada dasarnya tujuan seseorang untuk bekerja adalah untuk memperoleh penghasilan sehingga dapat digunakan untuk memenuhi kebutuhan hidup. Oleh karena itu, pemerintah terus berupaya untuk meningkatkan angka tingkat partisipasi angkatan kerja (TPAK), sebab ketenagakerjaan dapat menjadi sumber masalah kemiskinan Jika suatu wilayah memiliki jumlah penduduk yang berstatus tidak bekerja lebih banyak, maka akan berimplikasi pada peningkatan jumlah penduduk miskin. Meningkatnya penyerapan tenaga kerja sebagai modal untuk pembangunan daerah akan menjadi jalan untuk menurunkan tingkat kemiskinan yang terjadi.

Tujuan Penelitian ini yaitu untuk menguji dan menganalisis pengaruh Indeks Pembangunan Manusia dan Tenaga Kerja Terhadap Kemiskinan di Provinsi Sumatera Utara.

\section{METODE PENELITIAN}

Lokasi penelitian ini adalah Provinsi Sumatera Utara. Data yang dipilih adalah data kemiskinan, Indeks Pembangunan Manusia dan Tenaga Kerja di Provinsi Sumatera Utara. Sumber data yang digunakan dalam penelitian ini bersumber dari Badan Pusat Statistik (BPS), 
P-ISSN $2580-7781$

E-ISSN 2615 - 3238

\section{Metode Analisis Data}

Analisis yang digunakan dalam penelitian ini adalah metode kuantitatif. Analisis kuantitatif digunakan untuk mengetahui pengaruh Indeks Pembangunan Manusia dan Tenaga Kerja Terhadap Kemiskinan di Provinsi Sumatera Utara. Untuk menganalisa pengaruh terhadap analisa data ini dilakukan dengan menggunakan eviews10. Dalam model atau persamaan tersebut pengaruh indeks pembangunan manusia dan tenaga kerja terhadap kemiskinan dapat digambarkan dalam suatu bentuk fungsi berikut :

$$
Y=f(X 1, X 2)
$$

Dimana :

$\mathrm{Y}=$ Kemiskinan

X1 = Indeks Pertumbuhan Manusia (IPM)

$\mathrm{X} 2$ = Tenaga Kerja

Selanjutnya model diatas akan dimasukkan ke dalam persamaan regresi linear berganda (Hasan, 2015) :

$$
Y=\beta 0+\beta 1 X 1+\beta 2 X 2+u
$$

Dimana :

$\mathrm{Y}=$ Kemiskinan

X1 = Indeks Pertumbuhan Manusia (IPM)

$\mathrm{X} 2$ = Tenaga Kerja

$\beta 0=$ Konstanta

$\beta 1 . \beta 2=$ Koefisien Regresi

$\mathrm{u}=$ Variabel Pengganggu

(residual)

\section{HASIL PENELITIAN DAN PEMBAHASAN}

Hasil analisis data berguna untuk melihat pengaruh antara vaiabel IPM dan Tenaga Kerja terhadap variabel Kemiskinan. Hasil analisis menggunakan regresi linear berganda diperoleh dengan menggunakan program eviews10. Adapun hasil 
P-ISSN $2580-7781$

E-ISSN 2615 - 3238

analisis regresi linear berganda dan uji asumsi klasik yang diperoleh dari pengujian menggunakan program eviews10 sebagai berikut :

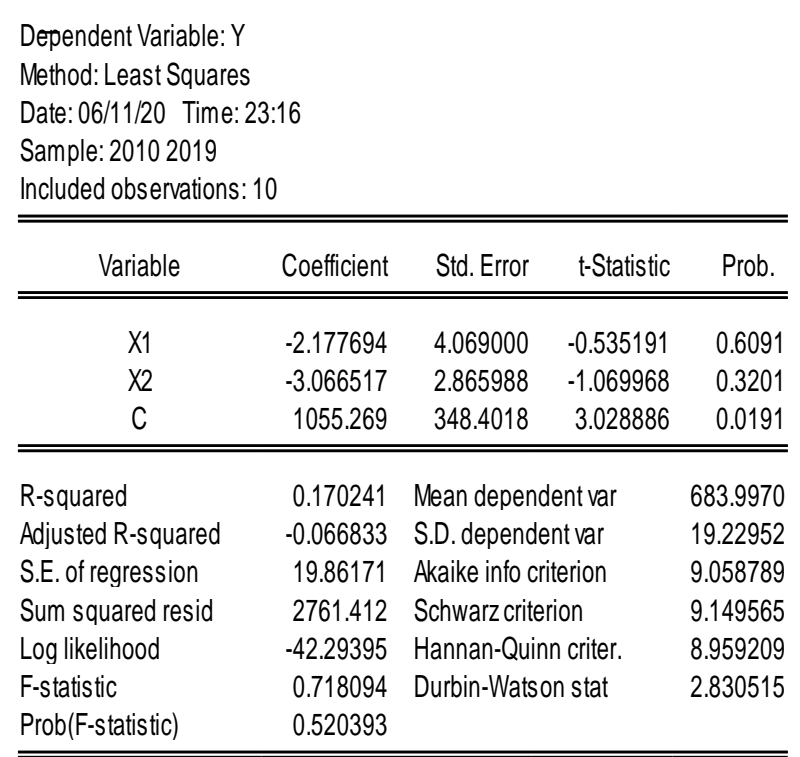

\section{Uji Simultan (Uji F)}

Dari hasil pengolahan data dengan melakukan uji simultan atau (uji F) maka secara simultan variabel IPM dan Tenaga Kerja terhadap variabel kemiskinan. Untuk menentukan nilai $\mathrm{F}$ tabel, maka digunakan tingkat signifikan 5\%. Hasil perhitungan Uji F yang diperoleh bahwa IPM dan Tenaga Kerja secara bersamasama tidak mampu menjelaskan Kemiskinan di Provinsi Sumatera Utara. Hal ini dijelaskan dengan nilai Fhitung $<$ Ftabel. Dimana nilai signifikan F yaitu 0,520 lebih besar dari 0,05 sehingga IPM dan Tenaga Kerja berpengaruh tidak signifikan terhadap Kemiskinan di Provinsi Sumatera Utara.

\section{Uji Parsial (Uji t)}

Dari hasil pengolahan data dengan menggunakan uji parsial (uji t) maka untuk menentukan nilai $\mathrm{t}$ statistik tabel digunakan tingkat signifikan 5\%. Berdasarkan dari analisis regresi diperoleh data mengenai perhitungan masingmasing variabel IPM dan Tenaga Kerja terhadap variabel Kemiskinan di Provinsi Sumatera Utara, dimana :

a Dari hasil pengolahan data menunjukkan $t$ hitung variabel IPM thitung $<$ tabel. Hal ini juga dijelaskan oleh nilai signifikan uji t yang diperoleh yaitu signifikan 0,60 dengan standar signifikan 0,05 maka nilai signifikan IPM lebih besar dari 0,05 maka Ho diterima dan Ha ditolak. Sehingga dapat disimpulkan bahwa 
P-ISSN $2580-7781$

E-ISSN 2615 - 3238

secara parsial IPM tidak berpengaruh signifikan terhadap kemiskinan diProvinsi Sumatera Utara.

b Dari hasil pengolahan data menunjukkan t hitung variabel tenaga kerja adalah thitung < ttabel. Hal ini juga dijelaskan oleh signifikan uji t yang diperoleh yaitu signifikan 0,320 dengan standar signifikan 0,05 maka nilai signifikan tenaga kerja lebih besar dari 0,05 maka Ho diterima dan Ha ditolak. Hal ini berarti tenaga kerja tidak memiliki pengaruh signifikan terhadap kemiskinan di Provinsi Sumatera Utara.

\section{Koefisien Korelasi $(\mathbf{R})$ dan Koefisien Determinasi $\left(\mathbf{R}_{2}\right)$}

Koefisien Korelasi $(\mathrm{R})$ diperoleh korelasi berganda sebesar $\mathrm{R}=0.53$ atau sebesar 53\% maka dapat disimpulkan bahwa terdapat hubungan keeratan korelasi yang kuat antara variabel IPM dan Tenaga Kerja terhadap Kemiskinan di Provinsi Sumatera Utara. Koefisien Determinasi $\left(\mathrm{R}_{2}\right)$ dari hasil perhitungan koefisien determinasi (R2) sebesar 0,06 atau 6\% artinya 6\% kemiskinan di Provinsi Sumatera Utara dipengaruhi oleh IPM dan Tenaga Kerja. Sedangkan 94\% dipengaruhi oleh variabel lain yang tidak diteliti.

\section{PEMBAHASAN}

\section{Pengaruh IPM terhadap Kemiskinan}

Berdasarkan hasil penelitian ini diperoleh bahwa IPM tidak berpengaruh dan signifikan terhadap kemiskinan di Provinsi Sumatera Utara. Dari persamaan diketahui variabel IPM menunjukkan koefisien sebesar - 2,177 artinya jika terjadi kenaikan IPM sebesar 1\% maka akan menurunkan kemiskinan sebesar $2.177 \%$ artinya setiap peningkatan IPM akan menurunkan persentase kemiskinan di Provinsi Sumatera Utara. Untuk variabel IPM diperoleh t hitung lebih besar dari $t$ tabel sehingga Ho diterima Ha ditolak.

Berpengaruhnya tingkat IPM terhadap Kemiskinan di provinsi Sumatera utara ini sesuai dengan teori pertumbuhan baru menekankan pentingnya peranan pemerintah terutama dalam meningkatkan IPM dan mendorong penelitian dan pengembangan untuk meningkatkan produktivitas manusia. Kenyataannya dapat dilihat dengan melakukan investasi pendidikan akan mampu meningkatkan kualitas sumber daya manusia yang diperlihatkan dengan meningkatnya pengetahuan dan keterampilan seseorang. Perusahaan akan memperoleh hasil 
P-ISSN $2580-7781$

E-ISSN 2615 - 3238

yang lebih banyak dengan mempekerjakan tenaga kerja dengan produktivitas yang tinggi, sehingga perusahaan juga akan memberikan gaji yang lebih tinggi kepada yang bersangkutan.

\section{Pengaruh Tenaga Kerja terhadap Kemiskinan}

Dari hasil penelitian ini diperoleh persamaan variabel Tenaga Kerja menunjukkan koefisien sebesar -3,066 artinya jika terjadi perubahan tenaga kerja sebesar 1\% maka akan terjadi perubahan terhadap kemiskinan sebesar $3.066 \%$ artinya setiap perubahan Tenaga Kerja akan mempengaruhi persentase kemiskinan di Provinsi Sumatera Utara. Untuk variabel Tenaga Kerja diperoleh t hitung lebih besar dari t tabel sehingga Ho diterima dan Ha ditolak. Dimana pada penelitian ini tidak ditemukan pengaruh antara tenaga kerja terhadap kemiskinan di Provinsi sumatera Utara. semakin tinggi pendapatan nasional atau daerah maka semakin besarlah harapan untuk pembukaan kapasitas produksi baru yang tentu saja akan menyerap tenaga kerja baru. Pendapatan yang tinggi tercermin dari tingginya pendapatan perkapita dan tumbuh secara positif dan berarti. Maka secara relatif semakin baik pertumbuhan ekonomi, maka semakin besarlah harapan untuk tidak menganggur sehingga akan mendorong pemerataan pendapatan perkapita sehingga mendorong meningkatnya indeks pembangunan manusia (Putong, 2009).

\section{KESIMPULAN}

Berdasarkan hasil penelitian mengenai pengaruh IPM dan Tenaga Kerja terhadap kemiskinan, maka dapat disimpulkan:

1. IPM tidak berpengaruh dan signifikan terhadap indeks kemiskinan di provinsi sumatera utara. Dari persamaan diketahui variabel IPM menunjukkan koefisien sebesar - 2,177 artinya jika terjadi kenaikan IPM sebesar 1\% maka akan menurunkan kemiskinan sebesar $2.177 \%$ artinya setiap peningkatan IPM akan menurunkan persentase kemiskinan di Provinsi Sumatera Utara. Untuk variabel IPM diperoleh $\mathrm{t}$ hitung lebih kecil dari $\mathrm{t}$ tabel sehingga Ho diterima $\mathrm{Ha}$ ditolak.

2. Dari hasil penelitian ini diperoleh persamaan variabel Tenaga Kerja menunjukkan koefisien sebesar -3,066 artinya jika terjadi perubahan tenaga kerja sebesar $1 \%$ maka akan terjadi perubahan terhadap kemiskinan sebesar 
P-ISSN 2580 - 7781

E-ISSN 2615 - 3238

$3.066 \%$ artinya setiap perubahan Tenaga Kerja akan mempengaruhi persentase kemiskinan di Provinsi Sumatera Utara. Untuk variabel Tenaga Kerja diperoleh thitung lebih kecil dari t tabel sehingga Ho diterima dan Ha ditolak. Dimana pada penelitian ini tidak ditemukan pengaruh antara tenaga kerja terhadap kemiskinan di Provinsi sumatera Utara.

\section{DAFTAR PUSTAKA}

Badan Pusat Statistik. Sumatera Utara. Indeks Pembangunan Manusia (IPM) Provinsi Sumatera Utara. BPS Sumatera Utara

Mulyadi S. 2003. Ekonomi Sumber Daya Manusia dalam Perspektif Pembangunan. Ed. 1.Cet 2. Jakarta: PT. Raja Grafindo Persada.

Putong, Iskandar. 2009. Pengantar Mikro dan Makro Edisi 4. Jakarta: Mitra Wacana M.

Todaro, M. P \& Smith, S. SC. 2006. Pembangunan Ekonomi Edisi Sembilan Jilid 1. Jakarta: Erlangga.

World Bank. 2004. Definisi Kemiskinan. http:/ /www. worldbank. Org (online). Diakses tanggal 12 Juni 2020 